The concluding portion of the address is a powerful plea for the adequate endowment of research of all kinds. As Prof. Appell showed, it is in research laboratories that advances in industrial processes are really made, and it is a wise economy to encourage the foundation of such institutions. The discourse should have an immediate beneficial effect on the further supply of higher scientific education in France, and it is probable that the lessons drawn by Prof. Appell from Charlottenburg and from similar American technical institutes will serve to demonstrate to French statesmen the importance of the subject with which the address deals with such ability.

\section{SOFT CHEESE-MAKING IN THE HOME COUNTIES.}

$T^{N}$ the rapid increase of grass land during the last thirty years, farming in the Home Counties has seen a remarkable change. The exhaustion of land by the too frequent growth of cereals during the period of high prices, and the fall in the price of corn since, made corn, as the main product of farming, unprofitable to cultivate in part of this district. The land has been laid, or in too many cases has been allowed to lay itself, down to grass, and, instead of corn, milk has now become the principal agricultural product. This change is most noticeable within a circle having London for its centre and a radius of thirty or forty miles, for milk is both bulky and perishable, and railway charges and time in transit both desiderate its production near the great centre of consumption.

It must not be supposed that the greater part of this area is particularly well suited for grazing purposes. On the contrary, unlike the west country, or the polders of Holland, where second year's grass has all the appearance of an old pasture, it takes twenty years to produce a good pasture on the London-clay or Boulder-clay soils. It was one of the most mischievous effects of the high price of corn in the middle of the last century that the good old pastures, which formed perhaps one-third of most of the farms, were broken up. Besides, even when a good pasture has been produced, the climate is not humid enough in summer to produce an abundant growth; it is rare to get more than one cut of meadow-hay in a season, and the aftermath generally provides indifferent grazing. Per acre, the returns in milk are therefore not great. No doubt the output might be greatly increased by introducing the Danish system of dairy-farming, i.e. growing a succession of green tillage crops for feeding the cows instead of pasturing them, but the scarcity of cheap labour, which is the most serious drawback to intensive farming in the neighbourhood of London, prohibits the practice of this system.

The time of year when the milk production is greatest is the month of May. From observations made in Essex last year it was found that the yield of milk in May was about 20 per cent. greater than in the winter, while during the summer it fell off to an equal extent as the quality of the grazing deteriorated. The consumption of $\mathrm{milk}$ in London, on the other hand, fluctuates but little, and farmers must therefore limit their sale to their minimum output, and are unable to take advantage of the flush of milk in the spring to increase their returns.

It is clear that dairy-farmers require some outlet for this surplus milk. To give it to the calves and pigs is to utilise it for a purpose for which foods purchased at half the price per food unit would serve equally well. Taking everything into consideration, the use to which it could most profitably be put is in the making of soft cheese, for which there is a ready demand whenever placed on the London market. Soft cheese-making requires none of the expensive appliances and little of the storage that are necessary for hard cheesemaking, and there is nothing to hinder its being carried out on any farm. But it needs knowledge and skill, and this is a subject of agricultural instruction, therefore, which the education committees in the Home Counties could most usefully provide.

Very opportunely, a little handbook on soft cheese-making has recently appeared, ${ }^{1}$ for the preparation of which the

1 "'The Practice of Soft Cheese-making." By C. W. Walker-Tisdale, P.I.C., and T. R. Robinson. F. S.I. Pp." sx. (L. W. W. Walker-Tisdale,
Dairy World and British Dairy Farmer, rgo3.) Price Is.

No. I 806 , VoL. 70] authors, in virtue of their experience at Reading and Wye, are particularly qualified. First and foremost they lay stress on the need for cleanliness in the handling of milk, for, as they point out, taints are far more noticeable, because further developed, in soft cheese than in the milk from which it is made. But even in the production of milk for sale, reform in the matter of cleanliness is badly needed. Nowhere probably in the whole of Europe are cows kept in a filthier condition than in parts of England and Wales, and it is not unknown to find in milk a sediment of hair, dust and dung, which points to dirty cattle. In Holland and Hungary the cows are regularly groomed, and this is not only done to prevent contamination of the milk, but also because the cows, being made more comfortable, do better and give more milk. Besides dirtiness of the cows, contamination of milk is due to a variety of causes-dust blowing in an ill-kept, windy byre, neglect of the milkers to wash their hands before milking or to put on a clean overjacket, the use of impure water for washing pails and churns, \&c., and it must be remembered that not only is such contamination an injury to the public, but it is sometimes the cause of loss to the farmers themselves when milk is returned to them as unsaleable. Short courses of instruction in the handling of milk for farmers and farm hands are badly needed. It may be doubted whether, without systematic science training, all the sources of bacterial contamination of milk can ever be guarded against, and it is to be urged that the county education committees should also provide for instruction in dairy bacteriology for those who, though a limited few, will, when distributed through the farming community, gradually spread the knowledge of the possible sources of bacterial contamination.

Once the principles of cleanliness have been mastered, the making of soft cheese is merely a matter of practice and attention to the details which are admirably set out in this little handbook. Of the sorts of cheese for making which directions are given, Bondon, Coulommier and Cambridge may be specially recommended, because they are milk cheeses and will consume the whole of the surplus milk on a farm, and because they need no ripening, and therefore require no storage accommodation. For the first-named especially there is known to be a good demand in London. They can all be made at any farm where a room capable of being kept at a uniform temperature is available, by the purchase of $5 l$. worth of appliances.

This is only one of the directions in which education committees in the Home Counties can directly aid the new style of farming, and in the neglect of which they will lose a splendid opportunity for usefulness. Greater productiveness of the land by more rational manuring, more economical feeding of dairy cattle, and improvement in the milk-producing qualities of dairy herds, are also needed to make the industry fairly profitable. In the writer's experience the majority of farmers feel their difficulties far too acutely to reject any means of improvement which are provided in a form of which they can make practical use.

T. S. D.

\section{INHERITANCE OF PSYCHICAL AND PHYSICAL CHARACTERS IN MAN. ${ }^{1}$}

$\mathrm{IN}$ his Huxley lecture, Prof. Karl Pearson gives the result of a prolonged investigation into the inheritance of the mental and moral characters in man (see NaTuRE, vol. 1xviii. p. 607 , October 22, 1903). His main conclusion is a remarkable one; it is that "the physical and psychical characters in man are inherited within broad lines in the same manner, and with the same intensity. . . We inherit our parents' tempers, our parents' conscientiousness, shyness and ability, even as we inherit their stature, forearm and span."

Great as are the obstacles in the way of a precise determination of the power of heredity in the physical sphere, those in the psychical are far greater. This arises partly from the difficulty of obtaining trustworthy evidence in the

1 "On the Inheritance of the Mental and Moral Characters in Man, and its Comparison with the Inheritance of the Physical Characters." The Huxley Lecture for roo3. By Prof. Karl Pearson, F.R.S. Pp. 179-237. 3 Hanover Square, London, W.) 
latter case, partly from the absence of any definite standard of measurement. Prof. Pearson, with characteristic ingenuity, has found means of overcoming both kinds of difficulty, and has succeeded in showing that for the inheritance of all observed traits, whether belonging to the "mental" or "bodily" category, the slope of the "regression" line closely approximates to the same value, viz. 0.5 . Considering the extent to which the personal element must needs enter into any estimate, however careful, of comparative ability or character, the uniformity shown by the author's tables is far greater than might have been expected. Some, indeed, may incline to the opinion that he proves too much, for if the influence of heredity is supreme alike in the mental and moral, and in the physical domain, what room is left for the action of teaching, training, discipline, and the environment generally, influences which the common experience of mankind has held to be of importance? Prof. Pearson partly meets the difficulty by reminding us that "the average home environment, the average parental influence is in itself part of the heritage of the stock." This is true enough, but scarcely covers the whole ground, because a great deal of the average environment is not parental.

Still, however firmly we may be convinced of the power of education to foster desirable qualities of whatever kind, there can be little doubt of the significance of the author's figures with regard to the material on which education and experience have to work. From these considerations there emerges a practical conclusion of the highest importance. "Intelligence," says Prof. Pearson, "can be aided and be trained, but no training or education can create it." "The mentally better stock in the nation is not reproducing itself at the same rate as it did of old; the less able, and the less energetic, are more fertile than the better stocks. No scheme of wider or more thorough education will bring up in the scale of intelligence hereditary weakness to the level of hereditary strength. The only remedy, if one be possible at all, is to alter the relative fertility of the good and the bad stocks in the community."

F. A. D.

\section{ANTHROPOLOGICAL NOTES.}

$W E$ have frequently directed attention to the splendid work done by Mr. Clarence B. Moore in his archæological investigations in Florida. In the second series ot the Journal of the Academy of Natural Sciences of Philadelphia, part iii. of vol. xii. is devoted to a memoir on certain aboriginal mounds of the Florida central west coast, and, like Mr. Moore's previous publications, it is sumptuously illustrated. Perhaps the most interesting find is a fish-spear of native copper ; this is a unique record for Florida. There is little doubt that the ancient coppersmith had arrived at the knowledge that hammering the metal gave it stiffness. Numerous copper ornaments were found, such as pendants and ear-plugs, some of the latter being decorated with symbolic designs. None of the skulls from this district exhibited cranial flattening, though it was extensively practised on the north-west coast of Florida. In the latter district were found ceremonial vessels in which large holes had been made before the firing of the clay, but they do not occur along the central west coast. The mounds on the Apalachicola River yield forms of burial similar to those prevailing along the north-west coast of Florida. Ceremonial vessels, "killed" by a basal perforation and by holes throughout the body, made before the firing of the clay, were found in considerable numbers; the ware is most inferior in quality, as might be expected of vessels purposely made for interment with the dead.

There was a spirited discussion in the American Anthropologist during 1903 concerning the origin of the sheet copper found in the Florida mounds. Mr. J. D. McGuire contended that it owed its origin to European influences, but the whole weight of evidence and experience was against him.

There is immense variety in the basketry of the native tribes of America as regards form, technique, decoration and the materials employed, and our colleagues of the United States fully realise the importance of studying the designs with which so many baskets are ornamented while there is yet an opportunity of discovering their significance, NO. 1806 , VOL. 70$]$
We have several times referred to this subject; the latest publication of this kind is an admirably and copiously illustrated memoir, by G. T. Emmons, on the basketry of the Tlinget, in the Memoirs of the American Museum of Natural History (vol. iii. part ii.). The accuracy with which designs have been preserved and transmitted through so many generations is evidence of the conservatism of primitive peoples; most of the patterns of the past may be seen in the work of to-day, but the modern tendency to produce new figures is born of the rivalry in trade. The old characters are being combined to form attractive though meaningless figures, and so symbolism in design will gradually be lost. In existing circumstances the future of basketry is not difficult to foresee; the younger generation learns to read and write, but seldom learns to weave, and so the time is not far distant when Alaska must follow in the footsteps of all the basket producing countries. It is fortunate that, in the meantime, we have such an admirable piece of work as Mr. Emmons has produced, as he has saved from oblivion the meaning of many patterns and designs.

The following ingenious method of ethnological investigation adopted by Mr. E. Thurston, superintendent of the Government Museum, Madras, is worth rescuing from the oblivion of the report for the year 1902-1903. "In the inquiries concerning manners and customs, a novel and eminently effective method of arriving at the truth concerning tribal ceremonials was resorted to, marriage and death ceremonies being acted in the form of theatricals in which each performer at the real ceremony was represented by a member of the class concerned. In this way the interest was thoroughly sustained, and the fatigue, which soon supervenes among illiterate people when they are interviewed, was avoided. Moreover, apparently trivial but really important points of detail were clearly brought out in a manner which is impossible by mere oral examination. I have myself had to play the part of maternal uncle, and, as representing the swami, to receive the obeisance of the mock bride. The leading rôle of corpse at a funeral was played either by an elderly man or by a clay votive figure purchased from a local potter. The pupils of the eyes of these figures are not painted in till they are taken to the temple, where puja is done to them, as it is the painting of the eyes which endows them with life."

In the report on the administration of the Government Museum of Madras for the year I902-1903, Mr. E. Thurston writes:- "Two tours were made in the course of the year. During the first of these the physical measurements of the jungle Uralis and Sholagas of the Coimbatore district were examined by myself, and their visual acuity, colour vision, \&c., by Dr. W. H. R. Rivers, of Cambridge. It took many months before confidence was restored among these primitive folk, who, as a report records, " could not understand why the measurements of the different organs of their bodies were taken; perhaps to reduce or increase the size of their bodies, to suit the different works which they were expected to do near London.' They believed, too, that the variously coloured wools, given to them for selection, were for tying them captive with. . . . A prolonged halt was subsequently made at Coimbatore, where the Kaikolans, Oddes, Oklkiliyans, \&c., were investigated. The Oddes, unfortunately, all have the title Boyan added to their names, and a fatal rumour was spread among them that the object of my visit was to transport the strongest among them to South Africa, to replace the Boers who had been killed in the war. My evil eye was cast on them, and they refused to fire a new kiln of bricks for house construction till my departure from their midst."

In appropriate yellow guise is published a new illustrated quarterly review called Buddhism, by the International Buddhist Society, at the Hanthawaddy Printing Works, Rangoon. The first article of the second number gives an account of the election and installation of the Taunggwin Sayadaw as Thathanabaing of Upper Burma. This functionary is the patriarch or ecclesiastic head, who is supreme in all matters connected with religion, and next to the king is the person most held in esteem. It is eight years since the last Thathanabaing died, and the people were as sheep without a shepherd, and feared that the Government would never exert its royal prerogative and elect a successor; but to their intense relief and satisfactior this was done in November, 1903. The review contains ai 